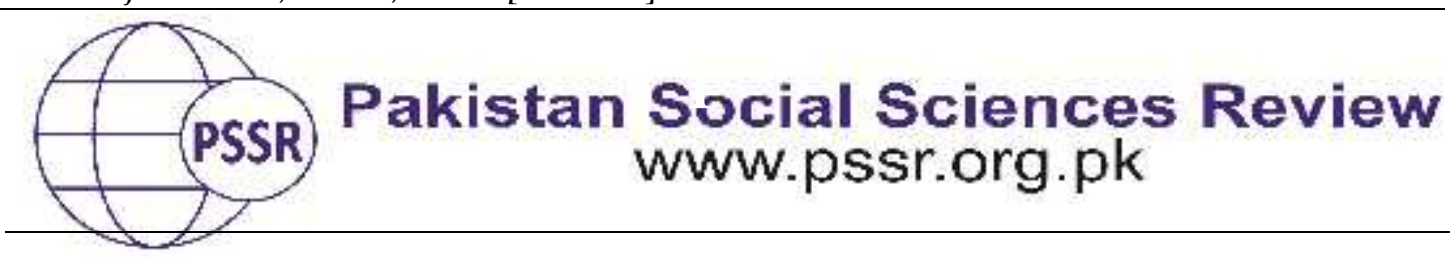

RESEARCH PAPER

\title{
General Muhammad Zia Ul Haq and Non Party Politics in Pakistan: An Analysis
}

\author{
Imran Khan ${ }^{1}$ Karim Haider Syed ${ }^{2}$
}

1. Lecturer, Government Graduate College Hafizabad, Punjab, Pakistan

2. Lecturer, Pakistan Study Center, University of the Punjab, Lahore, Punjab, Pakistan

\begin{tabular}{|c|c|}
\hline PAPER INFO & ABST \\
\hline $\begin{array}{l}\text { Received: } \\
\text { February 22, } 2017 \\
\text { Accepted: } \\
\text { June 24, } 2017 \\
\text { Online: } \\
\text { June 30, } 2017\end{array}$ & $\begin{array}{l}\text { This study explains the link between eleven years of rule of } \\
\text { General Zia Ul Haq and non-party politics in Pakistan. He after } \\
\text { assuming the power bans political activities in the country on } 5 \\
\text { July } 1977 \text { although political parties were not banned. All } \\
\text { political leaders were detained and house arrested. He assured }\end{array}$ \\
\hline $\begin{array}{l}\text { Keywords: } \\
\text { Elections, } \\
\text { Gen. Zia Ul Haq, } \\
\text { Martial Law, } \\
\text { Non Party } \\
\text { Politics, } \\
\text { PPP }\end{array}$ & $\begin{array}{l}\text { suspended some portions of the constitution of Pakistan. He } \\
\text { argued that he had to step in the political field when political } \\
\text { leadership failed to solve the crisis. He also emphasized on his } \\
\text { nonpolitical agenda and he stressed on his intentions for polls in } \\
90 \text { days according to the constitution (Newberg, 1995). In the } \\
\text { constitution of Pakistan political parties' act of } 1962 \text { was }\end{array}$ \\
\hline $\begin{array}{l}\text { Corresponding } \\
\text { Author: }\end{array}$ & $\begin{array}{l}\text { adopted in which elections in the country had to hold on party } \\
\text { basis. He assured the nation free and fair elections on party } \\
\text { basis in October 1977. With the passage of time he understood } \\
\text { one thing clearly that the return of PPP in power means his } \\
\text { removal from power and after it his trail under article } 6 \text { of the } \\
\text { constitution. To stop PPP in power Gen. Zia adopted non-party } \\
\text { politics as tool and survive for eleven years in power. This study } \\
\text { explains the nature, need and impact of non-party politics on } \\
\text { the politics of Pakistan. }\end{array}$ \\
\hline
\end{tabular}

\section{Introduction}

General Zia Ul Haq in his statements very clearly used to mention that he was not intended to continue in political office (Rizvi, 2005). On 29 July 1977 all political leaders were set free and two days later on 1st August 1977 the ban on political activities lifted and limited campaign for election process were allowed. Only eight days later an order was issued to get prior permission in case of party's public reception of their leader (Link,1983). As the date for his announced election was coming near he started to deviate from holding the elections. He changed his mind after assessment that PPP would come back in power and the consequences were very obvious for him. The change in the nature of the relations between Gen. Zia and 
Bhutto led the foundation of change of politics in Pakistan and Gen Zia seek shelter under the non-party politics to evade the return of PPP back in power and prolong his rule in Pakistan.

\section{Literature Review}

General Faiz Ali Chishti who served as corps commander Rawalpindi explains the details of Martial Law of Gen. Zia Ul Haq in his book The Betrayal of another kind" he said that the army had to intervene in that situation. Referring to General Zia-ul-Haq's "coup", he explained that he had clarified to Zulfiqar Ali Bhutto that the situation could not go on like this. Referring to General Zia-ul-Haq coup, he explained that political leaders were taken into custody that night and they were told that it was the order of the Army Chief so they were being detained in a dignified manner. Bhutto was shifted to Murree. General Chishti also wrote that a lot of papers were burnt in the Prime Minister's House that night. No one knew what was in them. Only Zulfiqar Ali Bhutto knew what was in them. He did not want these papers in the hands of the army. He shed light on the issue between Army and Z.A Bhutto and policies of General Zia Ul Ha during his era of power. This book is very important and has lot of material on the policies and politics of Gen Zia ul Haq (Chishti, 1989).

Shabir Hussain in his work Bhutto Yahiya and Zia explain that Yahiya Khan held free elections but in his desire to become the President of Pakistan he led the country to be disintegrated. From here, it became ingrained in the minds of the top brass of Pakistan security agencies that the country has been shattered by free elections. Therefore, they decided, there will be a controlled democracy in this country. Mustafa Khar, Bhutto's right-hand man, get resignation from General Gul Hassan at gunpoint, and when Bhutto shortened the life of his opponents, Zia-ul-Haq seized power from him. When Bhutto formed a political cell in the ISI, military decided to get in and continue that cell and controlled the democratic process. The author was witness of many events as journalist based in Islamabad his accounts matters. So his book has lot of details on the era of military rule in Pakistan (Hessian, 2000).

\section{Hypothesis}

Tthe political life of General Zia Ul Haq was directly linked with the nonparty based politics in Pakistan and he never allowed the party politics in the country throughout his era in power because he was anxious from popularity of PPP that could resulted in return of PPP back in power and in such case, he also was aware of the consequences for his rule and life.

\section{Non Party Politics and 1979 Local Bodies' Elections}

In September 1979 local bodies' elections held on nonparty basis and this was de jure nonparty type elections. In which law was abiding party basis elections but parties were existing. Meanwhile political parties were banned and could not 
participate in the elections but major political parties contested elections under appropriate disguise. Martial law regime allowed it to test the popularity of the people's party and other political forces (Ludra,2003). People's party in the local bodies' elections of 1979 cloaked under the name of people's friends, written on candidate's posters. Leagues were contesting elections under the cover name of "old servants" Whereas Islamic political alliances disguised themselves under the veil of "for an honest leadership" slogan printed on posters (Ali, 1983). Turn out in these local bodies poll were below 50 percent but workers of Pakistan peoples' party tried to show their abhorrence by participating in the elections. The results of the local bodies' elections were according to the assessment of military Junta and people's party won them with decisive majority. These results were final nail in the coffin of party politics under General Zia Ul Haq (Blood, 1995). He and his military Junta was not ready to return of people's party in power as they had ravished power from people's party and Bhutto, later of them had been demise. General Zia Ul Haq had announced the general elections would follow the local bodies' elections in November 1979 but he only one month before the announced date postponed them for indefinite time period. These local bodies' elections were testing tool for the popularity of people's party in public. Results were passive for military ruler as they had wrongly estimated that people's party would be buried with Bhutto in Larkana (The New York Times Biographical Service, 1986).

After Bhutto judicial murder, it was necessitated to ban people's party but to single out banning of people's party could not be helpful for the military regime. To stop any effort to run the people's party by changing its name, Junta forced total ban on all kind of political parties (Ganeri, 2002). General Zia Ul Haq had been consolidating his rule through shameless misuse of religion, repression and to introduce different political initiatives designed to calm the people of Pakistan for two years. He very shrewdly prolonged Bhutto trail for one and half plus year to create feelings of hope in people that deposed Bhutto would win at the end, by this he strength his power. General Zia Ul Haq sensibly during the period of Bhutto trail reassured the politicians that once the Bhutto affair was finished he would allow the elections. During this period he created a sigh of hope by disbanding Hyderabad tribunal and freeing the politicians involving in this tribunal (Hessian, 2000). After the postponement of the elections he started to threat the people using repressive code of medieval Islamic punishments. He used Islamic penalties against social and political dissenters and publicly flogged the political opponents (Muhammood, 1992). Executions of antagonistic political figures including women were very effective tool to lull the politicians. This was first time in the country that political workers were flogged in the main squares of the cities using lowed speakers to send their laments to other people for frightening. All what he done was going to brutalize the society and what we having observed in day to day business of the non-state actors in the country? The objectives of this institutional brutality were to ensure passivity in public, so that no one could oppose his ban on political parties and activities (Jafri, 2008). In 1979 General Zia Ul Haq hanged Bhutto and issued Islamic ordinances and held elections on non-party basis. Since he permanently deviated from the party based politics in the country in this year because he had seen threat for his life and 
rule in the party politics in the country (Chuhdhary and Mehmood, 2012). Local bodies' elections in 1979 became face saving for him as he was incessantly misstating about the polls. Poll did not hold according to constitution as party basis elections were mentioned in it. Before the election in 1979 he issued a local bodies' ordinance amending the 1962's one (Murri, 1990).

General Zia's Local Government Ordinance of 1979 differed from General Ayub Khan's Basic Democracies Ordinance of 1959 in many key respects. During the Bhutto regime Local government institutions were not active and power were used by Bureaucracy. Since the Colonial period of Pakistan area had principle of nonpartisan local level elections, however, the adoption of non-party based election's principle by Zia Ul Haq represented an important reversal because public based political parties had emerged as important players in the electoral history of Pakistan since the 1970, s general elections (Sansom and Mckinlay, 2013). General Zia Ul Haq considering political parties direct threat to his regime restarted nonpartisan principle in order to neutralize the influence of political parties at the local level. Chronological evidence advocated that these procedures resulted in the localization and personalization of politics at the local level and made politicians a local entities (Wilder, 1999).1979 local bodies' election was not substitute to the general election and people empowerment and local level did not satisfied political forces of the country. Local bodies' election was alarming tune for the military regime which after this election decided to ban political parties and left the idea of elected parliament (Jalal, 2014).

\section{Non Party Politics and Majlis-E- Shura 1980}

General Zia Ul Haq had declared party politics and opposition based assemblies as un-Islamic, he in 1980 created an Advisory Councils, named Majlis-eShura on the patron of the traditional consultative bodies that assisted medieval Muslim sovereigns and were still found in Gulf Arab states and Saudi Arabian monarchy. The Majlis-e-Shura was substitute of Parliament in Pakistan and to serve as an appointive legislative body to be nominated on non-party basis from parliamentary constituencies, with membership from cooperative groups including ex- military men and Ulema (Stephen and Marvin, 1988). Although Zia Ul-Haq promised the nation that Majlis- e-Shura would not smell of any autocracy, the fact that he had unilaterally distorted the constitution and chose for a selected legislature indicated otherwise. The members of the Majlis-e- Shura in center and provinces were chosen from the lists compiled by district commissioners in which hostile political groups had to participation. General Zia Ul-Haq argued that selected Majlis-e-Shura by the military on the bases of intellect and veracity, were favorable to parliament of the elected representatives. He also viewed that elections in the country had given birth only to goons and chaos and uncertainty.

Majlis-e-Shura of General Zia Ul-Haq comprised a large number of second-tier friendly politicians from mainstream political parties, wretched or bribed into cooperating with the military Junta. The discussions within these consulting bodies were basically Islamic as larger number of ulema and Islamist activists than any 
elected Pakistani legislature was presented in them. Members of the Majlis- Shura had no right to legislate for the country they just debated future laws on the basis of their basis of Islamic or otherwise(Haqqani, 2005).

\section{Non Party Politics and 1983's Local Bodies Elections}

Office term of Local bodies' government of 1979 was going to be expired in 1983. General Zia Ul Haq announced General elections in 1984 and before the elections held referendum and claimed land slid victory in the referendum. In 1983 the local bodies' elections for second term had been held under the new separate Constituencies system (Malik, 2006). Date for the general elections became useful as before the general elections he could again test the popularity of his hostile political party that was busy to overthrow him by political and apolitical means. Pakistan peoples' party after the death of Bhutto participated in non-party based local bodies elections of 1979 by using friends of people name in which it proved its popularity and existence without Zulifqar Ali Bhutto. After complete and strict ban on political activities some elements of the Peoples' party started militancy and tried to kill General Zia U1 Haq many times (Bahadur, 2008).

In 1983 peoples' party made a political move and created a political alliance of more than ten parties under the banner of MRD movement of restoration of democracy. To reduce the pressure of political and apolitical forces he announced general elections in 1985 and held local bodies' elections in 1983. He also favored political exploitation over consensus building to prolong his rule and to keep his hostile forces off balance. The announcement of elections did not, of course, satisfy the well-known political forces in the country (Burki, 1999). Local bodies' elections of 1983, exploited sectarian and ethnic sentiments of the Pakistani society. Similar tactics led to the birth of ethnic groups such as the Mohajir Qoomi Movement and the Punjabi-Pukhtun Ittehad along with saraiki Ittehad etc. Such tendencies were disastrous for national integration and only the results of nonparty based elections. The elections result of 1983 local bodies' government were again in favor of hostile parties to General Zia Ul Haq. He announced his commitment to hold nonparty based general elections (Thomas, 1988).

\section{Non Party Politics and 1984 Referendum}

General Zia Ul Haq wanted to establish such kind of democracy in Pakistan in which his rule could prolong and, he could rule as President with all powers under a civilian cloak. Although General Zia Ul Haq had seen his demise in survival of partisan politics so he took a number of steps to eliminate rule of political parties in political system of the country. In his first step he banned all political parties and hold nonparty based elections of local bodies in 1979. Second step was the establishment of the nonparty based Majlis-i-Shoora (Grover and Arora, 1997).This was to take the place of the parliament, but was to be lacking any legislative powers. General Zia's third step was referendum, in which he asked the public to endorse his rule. In the referendum people of Pakistan follow the call of MRD and boycotted the referendum 
of 1984 and turnout remained below 5 percent; it was defeat of General Zia regime (Taylor \& Francis Group, 2004).

Therefore, Zia preferred the nonparty general elections. There was nonparty based campaign in the country for referendum but he took shelter under the cloak of Islam. Only question in the referendum was to reply in yes or no the question "Whether the people of Pakistan approve the process initiated by the President of Pakistan, General Muhammad Zia-Ul-Haq, for bringing the laws of Pakistan in conformity with the Holy Quran and Sunnah of the Holy Prophet (PBUH) and for the protection of the Islamic ideology of Pakistan". Reply in yes means people had elected General Zia Ul Haq as president for next term for five years (Bhutto, 2004). Throughout the process of this referendum no political activity was allowed and no political question was also asked in the referendum. He held the referendum after a coup attempt against him. Second coup attempt against him forced him to think about transfer of power and civilian make up. He did not become ready to transfer power rather to share it. He announced general elections in end of 1984 and before holding the elections he made his position strong by referendum. Although this referendum was nonparty basis and fraud but General Zia Ul Haq used it as face saving (Wilder, 2009).

\section{Non Party Politics and General Elections of 1985}

In the election history of Pakistan this was second time when in the general elections political parties were barred to participate and candidates contested the elections in their individual capacities rather than in party capacities. First non-party elections were held in 1962 in which political parties were not allowed to participate and elections were through indirect representation system in which 80000 chosen people of basic democracies voted only. But in February 1985, the military government held direct election on adult franchise on nonparty basis. The objective of the 1985 election was same like the 1962 election, by General Ayub Khan, to civilianize military rule. General elections were long before postponed in 1979, on 12 August 1983 while addressing the federal Majlis e Shura session, General Zia Ul Haq made an announcement that he was going to hold general elections and would transfer the power to the elected representatives of the nation by March 23, 1985 (Weiss, 1991). One year later he in August 1984, declared that he might like to continue as President of Pakistan after the general election. Soon after this announcement he in October 1984, made a conditional handover of power and declared that power would be handed over to the elected representatives of the people only if they provided guarantee of the continuation of the Islamzation process introduced by his government. Only a week later he changed his stance and announced that he had no plan to transfer power but to share power with the elected representatives of the nation (Tahir, 1999). General Zia Ul Haq after securing the political future by holding referendum and assuming office of the president for next five years term decided to hold general election of National assembly on February 25 and provincial assemblies on 28, February 1985 (Bhutto,1989). The elections were hold on the principle of separated electoral in which the Muslim and non-Muslim voted 
separately for the candidates of their religion, whereas all previous national level elections direct or indirect were held on the principle of joint electoral. All Political parties were banned by military regime of General Zia Ul Haq to set aside peoples party from rejoining the power and parties were barred from participating in the election (Anwar, 1997). In 1979, General Zia Ul Haq amended the Political Parties Act, 1962, and put new legal restrictions on political parties. The amendments included: some of these as under:

- All political parties must submit an annual statement of income and expenditure with the Election Commission for scrutiny.

- All political parties must register with the Election Commission.

- The political parties must publish a political manifesto;

- All political parties will hold internal elections annually for their offices; and submit a list of office-bearers and ordinary members to the Election Commission (Abbas, 2005).

When plan, for the election were fixed for polling, people's party and majority of other political parties in MRD collation refused to register them with the Election Commission, prescribed conditions by the amendments in the Political Parties Act by the military government. Despite the fact that the political parties could not officially take part in the election, number of candidates with known political attachments at the local level contested the election in their own individual capacity (Rizvi, 2000)

There was duplicity in policy to ban the political parties as some political parties; particularly the Muslim League Pagaro and the Jamaat Islami silently supported their candidates in the elections as these were some of the friendly parties to General Zia Ul Haq. The ban on political parties from the election process resulted in the increase of contesting candidates. For 207 Muslim reserved seats there were over 1400 candidates filed nomination papers and nearly 4000 nomination papers were filed for 460 seats reserved for Muslims in provincial constituencies (Dorothy, 1992). A large number of political non entities were candidates in the elections as they wanted to take a chance because political parties were not contesting the elections. A new cadre of the politicians was going to be entered in the politics of the country as about one quarter candidates were fielded by tribal and feudal families along with religious leaders who could not stay away from politics. Many candidates were who made money during the last few years in manpower export to the Middle East, government contractors and real estate developers and middle ranking merchants (Ayub, 2013). . All such people who could spent wealth and enjoyed some support at the local level attempted to test their luck in the election. The military authorities strictly regulated the election campaign with a ban on public rallies and processions. Candidates only could hold small meetings in walled complexes (Degenhardt, 2002).

\section{Non Party Politics and Local Bodies' Elections of 1987}

Two years after the General elections and after the end of 1983 local bodies' government term 4 th consecutive nonpartisan elections held on 30 November 1987. In 
this 3rd local bodies' election political parties were once again barred to contest the election. Political parties participated in the election disguising in new name as Muslim League (friends of country) Peoples' party (Democracy lovers) MQM (rights lovers) Jamiat Ulema Pakistan (People of Prophet system) (Shahab, 2009). General Zia Ul Haq was closely monitoring the situation and being firm to held election on nonparty basis. In any election General Zia Ul Haq had experience popularity of Pakistan people's party triumph which was disastrous for his rule. He had made each and every try to finish the People's party but remained fail. He could not get rid of Bhutto as he was alive in shape of people's party and following him. General Zia Ul Haq after civilianizing his regime and using Islam for his legitimacy and efforts to crush party politics wanted to check results of his efforts and hold local bodies' elections in 1987. No political party was allowed to contest in these elections despite the fact that Juneejo government had allowed the party politics in the country. He after elections used undemocratic system of vote using show of hand in place of secret belt, during the process of choosing head of the local bodies' governments (Esposito, 1984). Results of the local bodies' elections were not hopeful for the country as political parties were not allowed to contest the elections. Apolitical, ethnic linguistic and sectarian groups emerged as main rivals in this election. MQM a student ethnic group of Sind won the majority in Karachi and Hyderabad. Political party's absence gave a chance to sectarianism, ethnicity and linguistic issues to overcome the main stream politics of the country and ultimately ruined the political culture of the country (Cloughley, 2008).

\section{Non Party Politics After 1987}

President General Zia-Ul-Haq on 29 May 1988 invoked article 58 2/B of the constitution and dissolved the National Assembly, dismissed the Government of Muhammad Khan Juneejo and assumed all powers again. He alleged that Juneejo government had started independence in the domestic and foreign policy field. He as army chief ordered the Army troops to take over the control of important government installations, including the P.M house, TV and radio station (Kashmiri, 1995).He also held responsible the Juneejo government of the slowing down of the process of Islamzation and remaining fail to maintain law and order situation in the country and uncontrolled corruption and worsening of public morals. He also announced new elections to be held to the National and Provincial Assemblies. He on 20 July 1988 fixed the date of the election as 16, November for National assemblies and 19, November for Provincial Assemblies respectively. He also made declaration for another nonpartisan election but toying with the idea of holding another nonparty election, he died in an aircraft crash on 17, August 1988.

\section{Conclusion}

The lack of countrywide socio-political and economic themes and multi-ethnic political grouping increased the role of narrow-minded identities based on Language, ethnicity, tribal identities, local community and sectarianism. These trends strengthened social divisions and caused greater disintegration of the political and 
social processes in the country (Malik, 2010). The rise of sectarian and ethnic terrorism is also legacy of General Zia Ul Haq that continues to dominate the political scene of Pakistan. This local issues based political system further weakened political parties. Sectarian and ethnic based groups increased strength in Pakistan because of the deliberately efforts of the military regime to undermine hostile political parties of the country. National and international level issues were skipped from campaign of elections and replaced with issues relating to local and constituency related affairs. Issues like construction of roads and street lights, better sanitation setting up of new schools and colleges in the constituency, improving of health and sanitation facilities (Baral, et.al., 2001). General Zia Ul Haq made everything in new state by introducing Party less local and central government system with new faces in politics on nonparty politics bases, new laws and regulations and make his try best to ride out party based politics in the country. So it can be said that there are three main Motive of Non- Party politics in Pakistan under Zia rule in Pakistan.

\section{Popularity of PPP}

One major reason was the popular support of Pakistan People's Party in Pakistani nation. General Zia Ul Haq whenever try to assess the level of popularity of PPP it remains intact that was direct threat to him due to his hostile policies towards PPP and extra constitutional actions. He did not want that PPP would come as force in the Parliament with whom he was going to share power (Nagy, 1995).

\section{Defeat in Referendum}

In the 1984 Movement for the restoration of democracy (MRD) gave call for boycott of the Referendum and people following the call did not participate in it. Below turnout was defeat of General Zia regime. Therefore he preferred the nonparty elections (Hasnat, 2011).

\section{Nonpolitical and Non-committed People in Parliament}

General Zia Ul Haq favored the non-Party elections because he knew very well that nonpolitical and non-committed parliamentarians were easy to control as compare to political and affiliated parliamentarians. Thus he sought that the people who become the member of the parliament they would not member of any party or to affiliated with any political leader. Majority of politically unknown landlords and member of the feudal families contested this election and their legacy is still in the parliament of Pakistan. 


\section{References}

Abbas, H. (2005). Pakistan's Drift into Extremism: Allah, the Army, and America's War on Terror. New York:M.E Sharp, New York.P 117

Ali, T. (1983). Can Pakistan Survive: The death of a State. London: W. W. Norton \& Company Incorporated.P137

Anwar, R. (1997). The Terrorist Prince: The Life and Death of Murtaza Bhutto. London: verso.P 148

Ayub, M. (2013). The Politics of Islamic Reassertion. New York: Rutledge.P147

Blood, P. R. (1995). Pakistan: A Country Study. Washington, D.C: Diane Publishers.P64

Bahadur, K(2008).Democracy in Pakistan: Crises and Conflicts. Karachi: Nation Publishers.P112

Burki, S. J. (1999). Pakistan: Fifty Years of Nationhood. London: West view press.P55

Bhutto, B. (1989). Daughter of Destiny, An Autobiography. London: Simon and Schuster.P 275

Baral, lok Raj, B. Pillai, B. \& ,RaisR. B. (2001). Governance and defense spending: views from South Asia. New Delhi: Regional Centre for Strategic Studies.P36

Cloughley, B. (2008). War, Coups and Terror: Pakistan's Army in Years of Turmoil. South Yorkshire: Casemate Publishers.P45

Chishti, F. A. (1989). Betrayals of another Kind: Islam, Democracy, and the Army in Pakistan. London: Tricolor Books.

Chuhdhary, A., Mehmood, W. (2012). Handbook on the South Asian Economies. Cheltenam: Edward Elgar.P66

Degenhardt, H. W. (2002).Revolutionary and dissident movements: an international guide. London: Longman.P234

Dorothy Q. (1992). Double Jeopardy: Police Abuse of Women in Pakistan. New York: Human rights watch.P21

Esposito, J. L. (1984). Islam and politics.New York: Syracuse University press.P186

Jafri, M. (2008).the Ideals of Bhutto. Karachi: Pakistan publisher.P253

Ganeri, A (2002). Indian subcontinent. London: Oxford University press.P36 
Grover, Verinder, Arora, R (1997). Pakistan, Fifty Years of Independence: Fifty years of Pakistan's independence: a chronology of events, 1947-97. New Delhi: Deep and Deep Publishers.P161

Hasnat, S. F. (2011). Pakistan. Santa Barbra: ABC CILO.P59

Hessian, S.S (2000). Ayub, Bhutto and Zia.Lahore: Singmil Publishers.P236

Hessian, S.S (2000). Ayub, Bhutto and Zia, Lahore: Singmil Publishers. 238

Haqqani, H, (2005). Pakistan between mosque and military.Washington: Carnegie Endowment for International Peace.P98

Haqqani, H, (2005). Pakistan between mosque and military. Washington: Carnegie Endowment for International Peace.P97

Jalal, A. (2014). Pakistan Struggle for homeland and global politics. New York: Harvard University press.P145

Kashmiri, K. (1995). General Zia key siasi tazadaat. Lahore: Aks e Jahan Publications.P160

Link, H. (1983). Volume 25, Issue 4, United India Periodicals. New Delhi, 1983. P104

Ludra, L.S. (2003). Operation "Qayamat": (a road map of the Pakistani jihad against India). New Delhi: Institute for Strategic Research and Analysis.P188

Malik, I. H. (2006). Culture and custom of Pakistan. Westport: Green wood press.P42

Malik, I. H.(2010).Pakistan: Democracy, Terrorism, and the Building of a Nation, London: Olive Branch Press.P34

Muhammood, M. D. (1992). The Judiciary and Politics in Pakistan: A Study. Lahore: Idara Mutalia-e-Tareekh.P150

Murri, M. K. B., (1990). A judge may speak. Lahore:Ferozsons.p57

Nagy, B. (1995). Pakistan, the land of the betrayed: a political $\mathcal{E}$ historical analysis.Lahore: Frontier publishers.P 303

Newberg, P. R. (1995). Judging the State: Courts and Constitutional Politics in Pakistan Cambridge: Cambridge University press.PP 161-162

Rizvi, H. A. (2005). The military and politics in Pakistan, 1947-1997. Lahore: Sange Meel Publishers. P 240

Rizvi, H. A. (2000). The military and politics in Pakistan, 1947-1997. Karachi: Oxford university press.P261 
Shahab, R. U. (2009). The political history of Pakistan. Lahore. Sangmil.P408

Sansom, G., Mckinlay, P. (2013). New Century Local Government: Commonwealth Perspectives. London: Common wealth Secretariat.p47

Stephen P. C., Marvin G. W, (1988). Pakistan in 1981: Staying On," Asian Survey, vol. 22, no. 2 February, 1981, p. 140.

The New York Times Biographical Service, (1986). Volume 17. New York: New York Times \& Arno Press, New York.P1163

Tahir, N. A. (1999). Problems of good governance in South Asian countries: learning from European political models. Karachi: University of Karachi.P69

Thomas, K. K. (1988). Asian Recorder: Volume 34. London: Recorder Press.P34

Taylor \& Francis Group (2004). Europa World Year. London: Taylor \& Francis Publishers.P3256

Wilder, A. (1999). The Pakistani Voters. London: Oxford University press.P124

Bhutto, F., (2004). Songs of the blood and Sword: a daughter's memoir (p.239). New York: Nation books.P239

Wilder, A. (2009). The Pakistani Voters. London: Oxford University Press.P28

Weiss, A. M. (1991). Culture, class, and development in Pakistan. London: west view press.P141 